\begin{tabular}{|c|c|c|c|c|c|c|}
\hline \multirow{4}{*}{ Impact Factor: } & ISRA (India) & $=3.117$ & SIS (USA) & $=0.912$ & ICV (Poland) & $=6.630$ \\
\hline & ISI (Dubai, UAE & $=0.829$ & РИНЦ (Russia & $=\mathbf{0 . 1 5 6}$ & PIF (India) & $=1.940$ \\
\hline & GIF (Australia) & $=0.564$ & ESJI (KZ) & $=8.716$ & IBI (India) & $=4.260$ \\
\hline & JIF & $=1.500$ & SJIF (Morocco & $=\mathbf{5 . 6 6 7}$ & OAJI (USA) & $=0.350$ \\
\hline
\end{tabular}

\section{SOI: 1.1/TAS DOI: 10.15863/TAS International Scientific Journal Theoretical \& Applied Science}

\author{
p-ISSN: 2308-4944 (print) e-ISSN: 2409-0085 (online) \\ Year: 2019 Issue: $04 \quad$ Volume: 72
}

Published: $11.04 .2019 \quad$ http://T-Science.org
QR - Issue
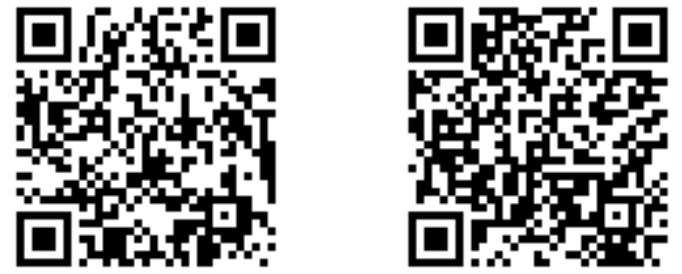

Jakhongir Pulatov

own researcher, the teacher of the chair of teaching methods of social-economic subjects, service and retraining territorial Centre of public education staff,

Uzbekistan

\title{
INTERRELATION OF THEORIES OF DEVELOPMENT AND THE CONCEPT OF HUMAN DEVELOPMENT (SOCIAL AND PHILOSOPHICAL ANALYSIS)
} \begin{abstract}
development, the main indicator is progress in human development. process.

Language: English

\section{Introduction}

There are various models of economic development (model of Germany, USA, China, the countries of Southeast Asia, Uzbekistan, Japan and other countries). Developed countries are distinguished in terms of economic development (USA, Japan, Germany, Sweden, France, etc.); developing countries (Brazil, India, etc.), including the least developed (mainly the states of Tropical Africa), as well as countries with economies in transition (former Soviet republics, countries of Central and Eastern Europe, China, Vietnam, Mongolia), most of which occupy an intermediate position between developed and developing countries.

The essence of progress was differently understood in sociology, philosophy, and economics. This understanding depended to a large extent on what criterion to take as the basis of this progress - the consciousness of freedom, the level of economic development, the achievements of science and technology.
\end{abstract}

Abstract: The relationship between theories of development and the concept of human development until the last quarter of the 20th century, each of these sciences chose its own, specific criterion of development, which led to an artificial separation of the concepts of economic development, social development, democratic and social progress. These developmental perspectives were combined only in the concept of human development. In the concept of human

Key words: Concept, development, human, humanistic, consciousness of freedom, level of development, economics, science and technology, model, progress, regress, national-cultural traditions, justice, social development, material benefits, social security, development society, human development, difficulty changing

Citation: Pulatov, J. (2019). Interrelation of theories of development and the concept of human development (social and philosophical analysis). ISJ Theoretical \& Applied Science, 04 (72), 79-81.

Soi: http://s-o-i.org/1.1/TAS-04-72-14 Doi: crossef https://dx.doi.org/10.15863/TAS.2019.04.72.14

\section{Materials and Methods}

The relationship between theories of development and the concept of human development until the last quarter of the twentieth century, each of these sciences chose its own, specific criterion of development, which led to an artificial separation of the concepts of economic development, social development, democratic and social progress. These developmental perspectives were combined only in the concept of human development. In the concept of human development, the main indicator is progress in human development. The formation of the concept took place as the result of a search for a single, universal, humanistically oriented development criterion. Such criteria embody the level of economic development, the achievements of science, the principles of management and the socio-political state of society, the level of education and health, the environment, as well as a way of life up to moral consciousness and worldview. "The concept of human development, notes Mahbub ul Haq, is in fact a comprehensive concept of development, encompassing both goals and means, both productivity and equity, both economic and social 


\begin{tabular}{|c|c|c|c|c|c|c|}
\hline \multirow{4}{*}{ Impact Factor: } & ISRA (India) & $=3.117$ & SIS (USA) & $=0.912$ & ICV (Poland) & $=6.630$ \\
\hline & ISI (Dubai, UAE & $=0.829$ & РИНЦ (Russia & $=0.156$ & PIF (India) & $=1.940$ \\
\hline & GIF (Australia) & $=0.564$ & ESJI (KZ) & $=8.716$ & IBI (India) & $=4.260$ \\
\hline & JIF & $=1.500$ & SJIF (Morocco & )$=5.667$ & OAJI (USA) & $=0.350$ \\
\hline
\end{tabular}

development, both material benefits and social provision [1]. In general, if we talk about the development of society, not only from the point of view of economic development, but also human development, this is a complex, contradictory and rather difficult-to-change process. This development is characterized by unevenness, it cannot be straightforward, in the ascending line, but includes periods of growth and recession, quantitative and qualitative changes, positive and negative trends. From this position it is necessary to talk about the socio-economic category of development.

As a social category, development is a process of reorganization and reorientation of the entire social system, including social and administrative structures, as well as in public consciousness, traditions and stereotypes. Social growth can play a positive role with an even distribution of its results, especially among vulnerable segments of the population. Other determining factors in expanding choices and opportunities are a long healthy life, education, the availability of an adequate standard of living, and the enjoyment of political and civil liberties.

The philosophers of antiquity, Democritus, Plato, Aristotle, Lucretius, and others tried to comprehend the nature of social development. A sample of the utopian social and political structure of society was portrayed by Plato (the dialogues "State" and "Laws"). The ideal state, according to Plato, is the just rule of the best by philosophers.

The concept of progress is inseparable from equality and social justice. This postulate, being one of the main aspects of the concept of human development, runs through the works of scientists and philosophers of the East, who also tried to assess the role of man in development. As the great Abu Ali Ibn Sina asserted, "a person becomes a person precisely because it satisfies the needs of others and others act in the same way. One plants the plants, another bakes bread, the third sews, the fourth makes a needle, and so everyone gathers to meet each other's needs. " [2]. According to the statements of A.Navoi, man is the most valuable, the best, "the most desirable of the created things" on the Earth. Everything is created for the sake of man and for him. "The purpose of all creations, the sun and the universe, mountains and plains, seas and rivers, plants and animals, flowers and nightingales, air and fire, the seasons of the year, i.e. all beautiful nature, its inexhaustible wealth, charms, is the service of man. "[3]. Beruni argued that the prosperity of the country is determined by the state of the sciences, their flourishing. According to Beruni, the highest happiness of a person is knowledge, since he is endowed with reason. Only such an understanding of happiness will bring peace and prosperity to society. "True pleasure is delivered only by the fact that the desire for something increases the more, the more a person owns it. And this is the state of the human soul when it comes to know what it did not know before " [4]., and the highest human dignity is caring for others and, especially, for poor people.

A significant contribution to the development of the concept of social development was made by scientists of the Enlightenment. Diderot considered man to be the highest value, the only creator of all the achievements of culture on earth, the rational center of the universe, the point from which everything should proceed and to which everything should return.

Jean-Jacques Rousseau, who was also looking for ways to combine a rational and justly organized social life, had a dialectical idea of combining progress and regress in social development. Thus, the emergence of inequality was both a manifestation of progress and a manifestation of regression in the development of society. It was a progress because it was based on the process of improvement, and regress - because, as a result of development, it won the race as a whole, the individual lost. The political ideal of Rousseau was direct democracy, carried out on the basis of a social contract, the essence of which is that "each of us gives our personality and all our strength under the supreme leadership of the common will, and together we accept each member as an indivisible part of the whole" [5]..

The essence of the philosophical and historical concept of Hegel's development is formulated in the words: "reason in history". The reason in history is carried out in such a way that every nation gets the right to contribute to the process of ascending selfknowledge of the world spirit. According to Hegel, history moves forward not as an automatic process; it is made up of the actions of individuals, each of whom seeks to realize their own interests and goals. At the same time, there are also some other, public results in which the "cunning of the mind of history" is hidden. This "trick" was noticed by an eminent British economist, the founder of the theory of market economy Adam Smith in his famous "Invisible Hand" principle. Every individual, according to Smith, striving to satisfy his interests and goals contributes to the achievement of public benefit: "in this case, as in many others, he goes with an invisible hand to a goal that was not at all part of his intentions. Pursuing his own interests, he often serves the interests of society more effectively. " [6]. It should be noted that the problems of development and the choice of the optimal criteria for its assessment are the most important research topic of representatives of various schools of philosophical thought.

The modern historical situation is unique and inimitable. Its uniqueness lies in the fact that in our epoch humanity faced common global problems, which brought it together with a common historical destiny caused by the global interdependence of the socio-economic, political and socio-cultural development of all countries and peoples. The uniqueness of modernity is determined by the diversity of development paths and types of economic 


\begin{tabular}{|c|c|c|c|c|c|c|}
\hline \multirow{4}{*}{ Impact Factor: } & ISRA (India) & $=3.117$ & SIS (USA) & $=0.912$ & ICV (Poland) & $=6.630$ \\
\hline & ISI (Dubai, UAE & $=0.829$ & РИНЦ (Russia) & $=0.156$ & PIF (India) & $=1.940$ \\
\hline & GIF (Australia) & $=0.564$ & ESJI (KZ) & $=8.716$ & IBI (India) & $=4.260$ \\
\hline & JIF & $=1.500$ & SJIF (Morocco & $=5.667$ & OAJI (USA) & $=0.350$ \\
\hline
\end{tabular}

systems, the difference in national cultural and political traditions of different countries. It is the effect of these factors that caused the emergence of a new paradigm of social development - human development. Taking into account these factors, social orientation towards human development is the most acceptable, perhaps the only effective way to achieve progress.

\section{Conclusion}

Human development is of particular relevance, which means that the reorientation of the economy towards solving social problems has acquired against the background of aggravating environmental problems. The solution of global and regional environmental problems is impossible without a transition to an "economy for man". This thesis is based on the studies of modern globalists, as well as on the works of the great Russian scientist and academician V.I. Vernadsky, who showed that as the biosphere turns into the noosphere, man and society become responsible for the reproduction of life on Earth.

Thus, the concept of human development is focused on the end result - on welfare, freedom and empowerment, and not on the means to achieve abundance, measured by real income and a set of goods and services. The development of the concept of human development made it possible to formulate a qualitatively new, promising approach to understanding social progress. This postulate, being one of the main aspects of the concept of human development, is traced in the writings of the great philosophers.

\section{References:}

1. Mahbub ul Haq (1995). Reflections on Human Development, chapters 2 and 3. Oxford University Press.

2. (1977). Tsit. po kn.: Ocherki istorii obshchestvenno- filosovskoy mysli V Uzbekistane. Pod red. I.M.Muminova i M.M. Khayrullaeva (Eds.). Tashkent: Fan.

3. Zakhidov, V. Y. (1961). Mir idey $i$ obrazov Alishera Navoi. Tashkent.

4. Russo, Z. Z. (1938). Ob obshchestvennom dogovore. (p.13). Moscow.

5. Smit, A. (1962). Issledovaniya o prirode $i$ prichinakh bogatstva narodov. (p.332). Moscow.

6. (1996, 2003). Doklad o chelovecheskom razvitii. UNDP.

7. Safarova, N. (2009). Terrorism: (tarikhiü-falsafil tahilil). Toshkent: Noshir. Library of Congress
Washington, DC 20540 United States.; Retrieved 2019, from http://searchworks.stanford.edu/

8. Tarushkin, A. B. (2004). Institutsional'naya ekonomika. (p.345). SPb: Piter.

9. Safarova, N., Aslanov, N. (2013). New Research Approach: Cognitive Abilities of a person. International Journal of Health Sciences. Vol. 1 No. 1, December 2013. http://ijhsnet.com/vol-1-no-1-december-2013ijhs

10. McNeill, D. (2007, March). Human Development: The Power of the Idea. Journal of Human Development, V 8, No. 1.

11. Safarova, N. O. (2010). Terrorism as a political phenomenon. International Journal of Academic Research. search.ebscohost.com. 